\title{
КОРРУПЦИОННЫЕ ПРОЯВЛЕНИЯ В ДЕЯТЕЛЬНОСТИ ДОЛЖНОСТНЫХ ЛИЦ В СФЕРЕ ЭКОЛОГИИ
}

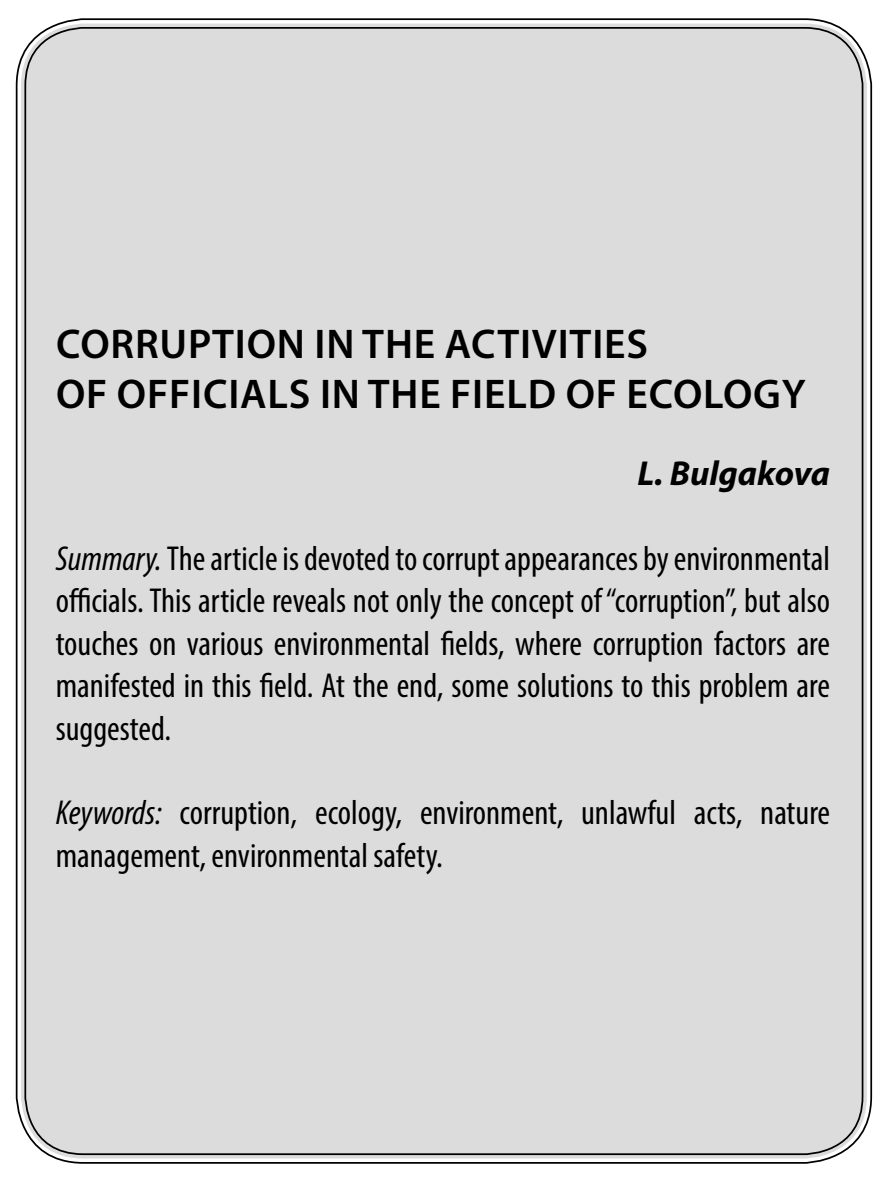

Д ля современного общества экология является весьма актуальной сферой и связано это с тем, что человек, в связи с боязнью нарастания экологических проблем, истощения природных ресурсов и иных экологических проблем, изменил свое отношение к окружающей среде. Многие страны мира уже давно проводят совместные мероприятия, форумы, различные съезды, которые в дальнейшем дают свои положительные плоды в сфере экологии.

Проблема коррупции в различных сферах деятельности органов государственной власти и местного самоуправления носит глобальный и системный характер. Важной составляющей процесса противодействия коррупции и соблюдения указанных ограничений являются меры административной и уголовной ответственности.

В настоящее время вопросу охраны окружающей среды и природопользования в Российской Федерации
Булгакова Луиза Сираджеддиновна Стариий преподаватель, Санкт-Петербургский юридический институт (филиал) Университета прокуратуры Российской Федерачии 6luiza@mail.ru

Аннотация. Статья посвящена коррупционным появлениям со стороны должностных лиц в сфере экологии. В данной статье раскрывается не только понятие «коррупция», а также и затронуты различные сфере экологии, где проявляется коррупционные факторы в указанной сфере. В конце предлагаются некоторые пути решения указанной проблемы.

Ключевые слова: коррупция, экология, окружающая среда, противоправные деяния, природопользование, экологическая безопасность.

уделяется особое внимание, в том числе и со стороны законодательной системы.

На постоянной основе в различные нормативно-правовые акты страны вносятся изменения в данной сфере, ответственность за нарушение которых ужесточается с каждым днем, однако данная мера не позволяет до конца искоренить коррупционные проявления в сфере экологии.

Сфера экологии и природопользования является потенциально коррупциногенной сферой, которая существует с древних времен и вопрос урегулирования затронут весьма непродуктивно.

Перед тем как рассматривать коррупционные проявления в сфере экологии и природопользования со стороны должностных лиц необходимо понять, что же такое коррупция в целом, в толковом словаре русского языка 
коррупция представляет из себя моральное разложение должностных лиц и политиков, выражающееся в незаконном обогащении, взяточничестве, хищении [5].

Юридическая литература под коррупцией понимает действия должностных лиц государственной власти, либо служащих коммерческих или иных организаций направленные на получения выгоды в виде денег, ценностей, либо иного имущества, путем совершения возложенных на них полномочий и обязанностей.

Также вышеуказанное понятие закреплено в ст. 1 Федерального закона от 25.12.2008 № 273-Ф3 «О противодействии коррупции» согласно которому, коррупция - это злоупотребление служебным положением, дача взятки, получение взятки, злоупотребление полномочиями, коммерческий подкуп либо иное незаконное использование физическим лицом своего должностного положения вопреки законным интересам общества и государства в целях получения выгоды в виде денег, ценностей, иного имущества или услуг имущественного характера, иных имущественных прав для себя или для третьих лиц либо незаконное предоставление такой выгоды указанному лицу другими физическими лицами; а также совершение деяний, от имени или в интересах юридического лица [6].

В Федеральном законе «Об охране окружающей среды» от 10.01.2002 № 7-Ф3 существует понятие как государственный экологический надзор, под которым понимаются деятельность уполномоченных федеральных органов исполнительной власти и органов исполнительной власти субъектов Российской Федерации, направленная на предупреждение, выявление и пресечение нарушений органами государственной власти, органами местного самоуправления, а также юридическими лицами, их руководителями и иными должностными лицами, индивидуальными предпринимателями, их уполномоченными представителями и гражданами требований, установленных в соответствии с международными договорами Российской Федерации, федеральными законами и принимаемыми в соответствии с ними иными нормативными правовыми актами Российской Федерации, законами и иными нормативными правовыми актами субъектов Российской Федерации в области охраны окружающей среды, посредством организации и проведения проверок указанных лиц, принятия предусмотренных законодательством Российской Федерации мер по пресечению и (или) устранению последствий выявленных нарушений, и деятельность уполномоченных органов государственной власти по систематическому наблюдению за исполнением обязательных требований, анализу и прогнозированию состояния соблюдения обязательных требований при осуществлении органами государственной власти, органами местного самоуправ- ления, юридическими лицами, индивидуальными предпринимателями и гражданами своей деятельности.

Вышеуказанный надзор осуществляется уполномоченными федеральными органами исполнительной власти (федеральный государственный экологический надзор) и органами исполнительной власти субъектов Российской Федерации (региональный государственный экологический надзор) (далее - органы государственного надзора) согласно их компетенции в соответствии с законодательством Российской Федерации в установленном порядке.

Государственный экологический надзор включает в себя:

- государственный надзор за геологическим изучением, рациональным использованием и охраной недр;

- государственный земельный надзор; - государственный надзор в области обращения с отходами;

- государственный надзор в области охраны атмосферного воздуха;

- государственный надзор в области использования и охраны водных объектов;

- государственный экологический надзор на континентальном шельфе Российской Федерации и иное.

Возникает вопрос, почему коррупция в сфере экологии столь актуальна.

Дело в том, что экология это не паханое поле различных благ, такие как земля, недра, леса, животный мир и иное.

К основным коррупциногенным сферам в области экологии и природопользования в Российской Федерации можно отнести следующие направления:

- незаконная добыча природных ресурсов;

- незаконная вырубка лесных насаждений;

- загрязнение атмосферы, водоемов, почвы;

- контрабанда животных, а также объектов флоры и фауны;

- выдача должностными лицами различных лицензий и иные противоправные деяния в изучаемой сфере.

Эти и многие другие направления являются востребованными и несут за собой правонарушения коррупционного характера как со стороны должностных лиц, так и с другой стороны.

Проявления коррупции в природопользовании весьма разнообразны, что связано с большим количеством 
природных ресурсов и компонентов природной среды (земля, недра, животный и растительный мир), а также с возможностями распоряжаться ими.

Согласно статистическим данным 15\% уголовных дел коррупционной направленности относятся к сфере экологии и возбуждены в отношении должностных лиц [2], большая часть указанных дел возбуждена в связи с такими правонарушениями как:

1. Получение определенных лицензий на использование вод, лесов, атмосферного воздуха, недр, животного мира, а также иных лицензий, предусмотренных законодательством Российской Федерации.

2. Незаконное пересечение таможенной границы Российской Федерации, путем содействия в уклонении от уплаты таможенных платежей, перевозки объектов флоры и фауны и иное;

3. Уклонение от уголовное ответственности и административной;

4. Охрана незаконной добычи природных ресурсов от правоохранительных и иных контрольно-надзорных органов.

Данный список является не исчерпывающим, однако данные «услуги» являются наиболее востребованными и как следствие является высокооплачиваемыми.

Рассмотрим такую сферу в экологии как лесопользование, коррупция в данной сфере сопровождается на всех этапах, например: выделение лесных участков, незаконная рубка лесных насаждений, заготовка леса, транспортировка и сбыт леса.

В указанной сфере есть ряд определенных действий со стороны должностных лиц, за совершение которых указанные лица получают определенное вознаграждение:

1. Выделение лесных участков в пользование: проведение конкурсов и аукционов с нарушениями требований федерального законодательства, незаконное предоставление различных участков различной категории для проведения лесозаготовок под видом санитарных рубок и иное.

2. При осуществлении заготовки леса: бесконтрольная рубка без разрешительных документов, вне предел предоставленных участков, несоответствие предоставленным объемам.

3. При транспортировке и сбыте: обеспечение бесконтрольного перемещения срубленного леса и иное.

Анализируя судебную практику, можно сделать вывод, что сфера недропользования является весьма проблематичной сферой и самые распространенные нарушения в данной сфере является безлицензионная добыча полезных ископаемых: гравия, песка, песчано-гравийных отложений.

Указанные нарушения причиняются ущерб в том числе и водным объектам, рыбному хозяйству, природной среде и иное.

Затрагивая сферу недропользования, можно выделить ряд различных коррупционных проявлений, связанные с сокрытием нарушений в указанной сфере:

1. Незаконное использование недр, без разрешительных документов, при осуществлении строительства, размещения и иное;

2. Ненадлежащее использование недр, либо их использование вопреки выданной лицензии;

3. Добыча полезных ископаемых сверх установленного в лицензии объема;

4. Использование недр по незаконно полученной или просроченной лицензии и др.

Хотелось бы отметить, что нарушения в сфере добычи песчаногравийной смеси выявляются крайне редко.

Основная часть нарушений допускается со стороны местной администрации при заключении соглашения на благоустройство и укрепление берегов рек.

Также одной из весьма коррупционных направлений является охрана и использование водных объектов, так например:

1. Сокрытие правонарушений выявленных контролирующими органами в ходе проведенной проверки;

2. Осуществление водопользование без разрешительных документов и иное.

Объекты животного мира, флоры и фауны также являются весьма коррупционной сферой. Браконьерство на сегодняшний день весь распространенный вид правонарушения, попустительство со стороны должностных лиц также сопутствует указанному проявлению.

Еще одним видом преступления является перемещение через границу редких видов животных, в том числе занесенных в Красную книгу.

В заключение следует отметить, что борьба с коррупцией в указанной сфере является весьма актуальной.

Для достижения успеха в борьбе с указанными преступлениями необходимо всем органам власти объединить усилия путем четкого распределения действий среди правоохранительных, контролирующих и надзирающих органов. 
Кроме того, необходимо совершенствовать законодательство в указанной сфере с целью устранения коллизий, противоречий, деклараций и пробелов и развивать единую систему государственного контроля в сфере природопользования на основе применения единых государственных стандартов.

Также одним из эффективных методов борьбы является повышении уровня подготовки руководителей органов государственной власти и местного самоуправления, наделенных правом принимать решения в сфере экологической безопасности. Президент России отметил, что не должно быть так, чтобы решения по защите окружающей среды зависели от людей, которые сами и воду чистую пьют, и живут в хороших экологических условиях, а огромные трудовые коллективы и все, что вокруг, движется и живет неблагоприятной экологической ситуации [4].

Кроме вышеизложенного, не надо забывать, что повышение экологической грамотности населения, также влияет на общую картину.

С другой стороны, необходимо обеспечить предусмотренную законом ответственность за коррупционные нарушения: административную, дисциплинарную, гражданско-правовую [1]. При этом, объяснить гражданам, что уголовной ответственности подлежат не только должностные лица, но и любые физические лица [3].

\section{ЛИТЕРАТУРА}

1. Воронцов С.А., Ляхов В.П. 0 дисциплинарной, административной и гражданско-правовой ответственности государственных и муниципальных служащих за коррупционные правонарушения // Наука и образование: хозяйство и экономика; предпринимательство; право и управление. 2015 .№ 4 (59). С. $54-61$.

2. Краткая характеристика состояния преступности в Российской Федерации в январе-декабре 2018 года Доступ: https://мвд.pф/reports/item/17926489/. Дата обращения: 09.01.2020.

3. Понеделков А.В., Воронцов С. А. Основные направления государственной политики Российской Федерации в области противодействия коррупции // Вестник Поволжского института управления. 2015. № 1 (46). С. 4-11.

4. Правосознание. Доступ: http://www.pravosoznanie.org/2545

5. Толковый словарь русского языка. С. И. Ожегов, Н. Ю. Шведов. Доступ: https://slovarozhegova.ru/word.php?wordid=12029. Дата 0бращения: 09.09.2019.

6. Федеральный закон от 25.12.2008 № 273-Ф3 «0 противодействии коррупции» // Собрание законодательства РФ.— 29.12.2008.— № 52 (ч. 1). — Ст. 6228.

(с) Булгакова Луиза Сираджеддиновна ( 6luiza@mail.ru ).

Журнал «Современная наука: актуальные проблемы теории и практики»

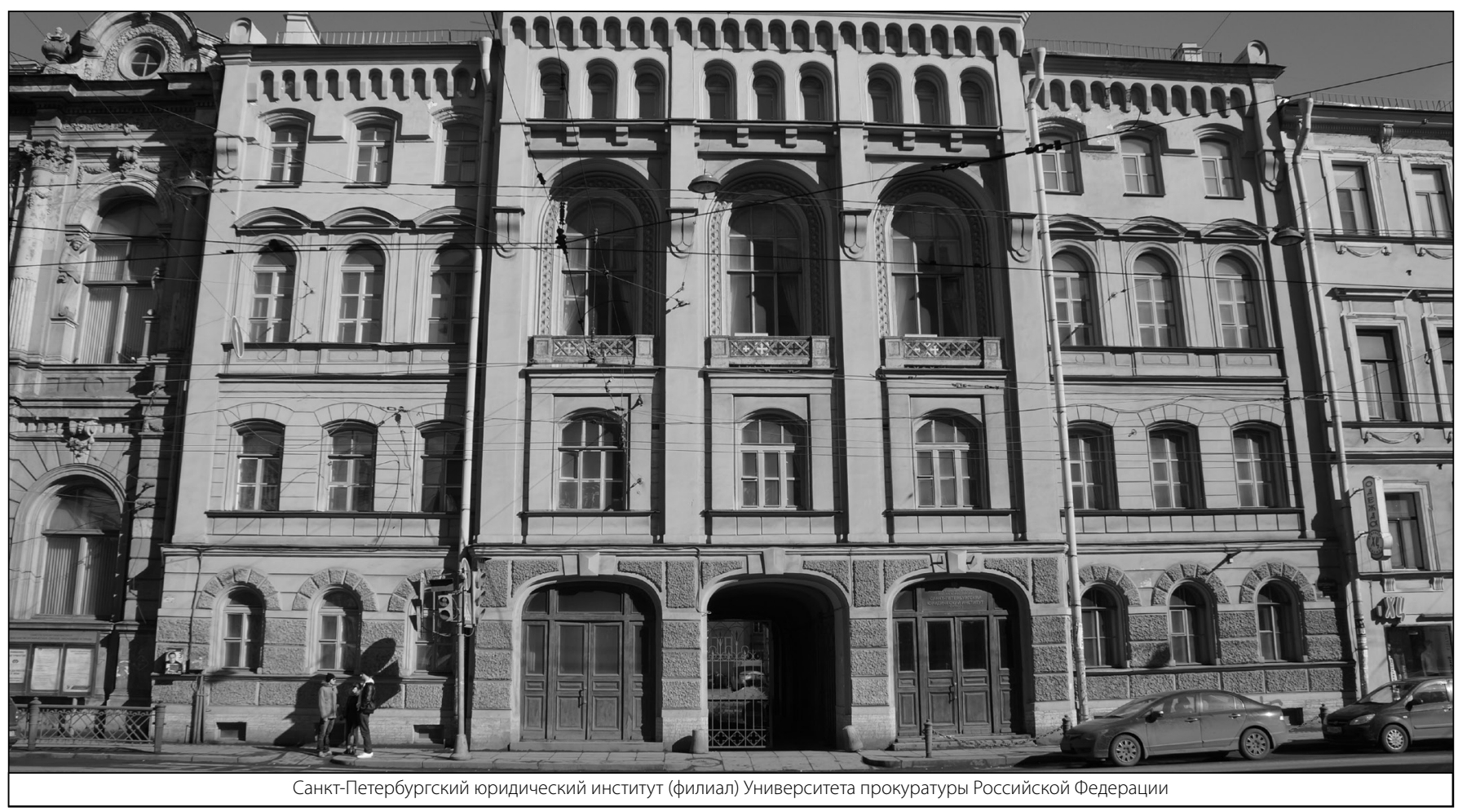

